\title{
Blood-Glucose Levels of Rats Given High-Fat Diets after Administration of Neem Leaf Ethanolic Extract
}

\author{
Sri Isdadiyanto*, Siti Muflichatun Mardiati, Agung Janika Sitasiwi \\ Department of Biology, Faculty of Science and Mathematics, Universitas Diponegoro, Indonesia \\ *Corresponding Author: isdadiyanto@yahoo.com
}

Submitted: 2021-03-17. Revised: 2021-05-29. Accepted: 2021-07-25

\begin{abstract}
Azadirachta indica A. Juss (Neem) is a medicinal plant that contains antioxidants, antihyperlipidemia, and has antidiabetic activity. This research aimed to examine the effect of neem leaf ethanolic extract on blood glucose levels of white rats given high-fat rations. The male white rats (Rattus norvegicus L.) with two months of age were used. The treatment of test animals consisted of six treatment groups and four replications, namely: the control group (P0); given high fat rations + duck egg yolk $2.5 \mathrm{ml} / 200 \mathrm{gBW}$ (P1); given high-fat rations $+8 \mathrm{mg} / 200 \mathrm{gBW}$ simvastatin $(\mathrm{P} 2)$; and $\mathrm{P} 1+$ the dose of neem leaf ethanolic extract of 75 ; 100 ; and 125 $\mathrm{mg} / 200 \mathrm{gBW}$ (P3; P4; and P5). Blood-glucose levels were analyzed by colorimetric enzymatic method using Roche Diagnostics Cobas C reagents kits. Blood-glucose level was determined using Roche / Hitachi cobas c systems automatically. Homogeneous and normally distributed data of blood-glucose levels, body weight and feed consumption were analyzed statistically using ANOVA followed by Duncan's test with a significance level of 5\% using SPSS 16.0 software. The results indicated that giving the neem leaf ethanolic extract of could reduce the blood glucose levels. In this study, it was concluded that the neem leaf ethanolic extract of could potentially be used as an alternative to cure diabetes mellitus.
\end{abstract}

Key words: hyperlipidemia; diabetes mellitus; used cooking oil; blood-glucose; medicinal plant

How to Cite: Isdadiyanto, S., Mardiati, S. M., \& Sitasiwi, A. J. (2021). Blood-Glucose Levels of Rats Given High-Fat Diets after Administration of Neem Leaf Ethanolic Extract. Biosaintifika: Journal of Biology \& Biology Education, 13(2), 142-148.

DOI: http://dx.doi.org/10.15294/biosaintifika.v13i2.29516

\section{INTRODUCTION}

The times have gradually influenced people's lifestyle and diet. People today tend to have a habit of consuming high-fat foods which can lead to an increase in the prevalence of degenerative diseases, one of which is diabetes mellitus (Foley et al., 2019). Type 2 diabetes accounts for $90 \%$ of all diabetes cases and is characterized by insulin resistance and damage to the insulin-secreting pancreatic cells. Hyperlipidemia plays an important role in the pathogenesis of $\beta$ cell dysfunction among many contributing factors (Hao et al., 2007). Hyperlipidemia is identified by an increase in total cholesterol, low density lipoprotein (LDL), and very low density lipoprotein (VLDL), and reduced levels of high density lipoprotein (HDL). Foregoing research shows that excessive consumption of highfat rations results in insulin resistance (IR) because of the presence of saturated fatty acids which can affect insulin action (Munshi et al., 2014).

Increased free fatty acids, intracellular triglyceride deposits, and cholesterol are found in obese patients, this is called metabolic overload (high intake of calories and fat). This event can decrease the tissue response to insulin. Higher fatty acids affect changes in insulin secretion in $\beta$ cells (McCance \& Huether, 2014). Adipose tissue in obese people causes an increase in non-esterified fatty acids, hormones, pro- inflammatory cytokines, glycerol and other factors that affect insulin resistance. Pancreatic $\beta$ cell dysfunction accompanied by disorder on the islets of Langerhans which release insulin and can cause error to set blood glucose levels. Abnormality of $\beta$ cell function is very important in determining the hazard and growing of type 2 diabetes (Kahn et al., 2006).

Insulin resistance can also be caused by oxidative stress. It is suspected that oxidative stress has an impact on the damage to acinar cells, thereby triggering autodigestion of the pancreas (Verlaan et al., 2006) which leads to pancreatic $\beta$ cell necrosis (Tjahjono et al., 2013). Trans-fatty acids is believed to be a source of oxidative stress (Martin et al., 2007). Trans-fatty acids can be obtained from oil that is used for frying repeatedly. Repeated frying can convert unsaturated fatty acids into trans-fatty acids, free radical compounds, and peroxide groups. Trans-fatty acids can increase LDL cholesterol levels, but at the same time reduce HDL cholesterol levels (Tuminah, 2009). Sartika et al. (2016) through their research revealed that there was a reduce in the number of normal $\beta$ cells pancreas of Wistar rats which were fed with trans-fatty acids. This study was supported by Dusaulcy et al. (2019) who stated that feeding highfat feeds to white mice could affect the expression of pancreatic $\beta$ cell genes which could cause pancreatic $\beta$ cell dysfunction and apoptosis. 
A. indica (Neem) is including of the Meliaceae family that plays a role in improving health because it is rich in antioxidants. This plant has been widely used as medicine throughout the world such as China, Ayurvedic, and Greece, especially in India for the recovery and prevent several diseases. Studies based on animal models showed that neem is a safe medicinal plant and is able to modulate many biological processes without side effects (Alzohairy, 2016). Neem is a herb medicine used in Ayurveda to recover several diseases, one of which is as an antihyperlipidemic. This is because neem is known to have anti-inflammatory, antipyretic, antimicrobial, anti-diabetic, and various other pharmacological effects (Satyanarayana et al., 2015). Jannah et al. (2020) reported their results that neem is useful as an alternative treatment for vascular disease.

Biologically active compounds contained in plant extracts include alkaloids and phenolic compounds for example steroids, ketones, carotenoids, flavonoids, and triterpenoids (Debashri \& Mondal, 2012). Neem leaf extract analysis showed that it has 6 compounds, especially quercetin-3-O-L-rhamnoside, kaempferol-3-O-B-D-glucoside, quercetin-3-ORoutoside, kaempferol-3-o-Routoside, myricetin-3-0Routoside, quercetin-3-O-B-D-glucoside (Chattopadhyay, 1999). Furthermore, it was said that neem at a dose of $500 \mathrm{mg} / \mathrm{kgBW}$ can decrease the levels of cholesterol in diabetic-induced rats (Chattopadhyay \& Bandyopadhyay, 2005). TembeFokunang et al. (2019) proved that the compounds in neem leaves can decrease the hazard of heart and blood vessel disease caused by high cholesterol levels. Isdadiyanto et al. (2020) stated that white mice given high-fat rations and 44 days of exposure to neem leaf ethanolic extract showed an increase in HDL concentrations and a decrease in triglycerides and LDL concentrations.

Based on these facts, it is necessary to conduct a research on blood serum glucose levels of white rats Wistar strain which are fed with high-fat ration after being treated with the ethanol extract of neem leaves (A. indica). This study is expected to provide benefits regarding the potential of neem leaves $(A$. indica) and their benefits in the health sector in the context of developing knowledge related to nonpharmacological treatment and as a reference for further study.

\section{METHODS}

\section{Creating high-fat ration}

The high-fat ration in this study consisted of commercial feed mixed with used cooking oil. A mixture of commercial feed and used cooking oil was prepared by adding every $30 \mathrm{~g}$ of commercial feed with $3 \mathrm{ml}$ of used cooking oil. Reused cooking oil was obtained from frying tofu weighing $450 \mathrm{~g}$ for 10 minutes at a temperature of $150-165{ }^{\circ} \mathrm{C}$ with a deep fat frying technique using one liter of cooking oil (Muhartono et al., 2018). The frying process was carried out nine times (Hanung et al., 2019). Subsequently, high fat ration was given to mice as much as $30 \mathrm{~g} /$ day and duck egg yolk was given as much as $2.5 \mathrm{ml}$. Results of proximate and cholesterol analysis of ration are presented in Tables 1 and 2.

Table 1. Proximate analysis results of commercial ration and commercial ration + used cooking oil

\begin{tabular}{lcc}
\hline Kinds of analysis & Commercial ration & Commercial ration + used cooking oil \\
\hline Water $(\%)$ & 10.78 & 9.84 \\
Ash $(\% \mathrm{wb})$ & 6.26 & 5.71 \\
Fat $(\% \mathrm{wb})$ & 4.70 & 12.07 \\
Protein, fk: $6.25(\% \mathrm{wb})$ & 17.92 & 17.23 \\
Crude fiber $(\% \mathrm{wb})$ & 2.49 & 2.26 \\
carbohydrates by diff $(\% \mathrm{wb})$ & 60.35 & 55.16 \\
Calories $(\mathrm{kcal} / 100 \mathrm{~g})$ & 328.96 & 373.36 \\
\hline
\end{tabular}

Table 2. Results of ration cholesterol analysis

\begin{tabular}{lll}
\hline Kinds of analysis & Commercial ration & Commercial ration + used cooking oil \\
\hline Cholesterol (mg / g) & 0.48 & 0.74 \\
\hline
\end{tabular}

\section{Preparation of the neem leaf ethanolic extract}

The neem leaf were amassed from campuss area of Diponegoro University. Furthermore, the leaves were oven-dried for ten days at $40-50{ }^{\circ} \mathrm{C}$ and extracted with the maceration method using $70 \%$ ethanol (Hasana et al., 2019). The dried neem leaves were blended to become a powder. One hundred grams of neem leaf powder was extracted with a ratio of 1: 3 of the neem leaf powder and the solvent. Then the solution was macerated for 48 hours in a closed room by shaking it using a rotary shaker. After 48 hours, the sample was filtered using filter paper and then collected in an Erlenmeyer flask. Afterward, the filtrate was evaporated with a rotary evaporator at a temperature of $40^{\circ} \mathrm{C}$ until a concentrated extract was obtained in the form of a powder (Supriyanto et al., 
2017).The extraction results were maintained in $4{ }^{\circ} \mathrm{C}$ in a closed frosted jar.

\section{Treatment of test animals}

This study used twenty-four male white rats Wistar strain aged two months with $200 \mathrm{~g}$ average weight. White rats were acclimatized under laboratory conditions for 1 week by placing 1 mouse in each rearing cage. Rats were fed and drank $a d$ libitum. Test animals were weighed and tested for cholesterol levels before being given the treatment. This research used a Randomized Complete Block Design by an experimental study. The treatment of test animals consisted of six treatment groups and four replications, namely: the control group (P0); given high fat rations + duck egg yolk 2.5 $\mathrm{ml} / 200 \mathrm{gBW}$ (P1); given high-fat rations +8 $\mathrm{mg} / 200 \mathrm{gBW}$ simvastatin (P2); and $\mathrm{P} 1+$ the dose of neem leaf ethanolic extract of $75 ; 100$; and 125 $\mathrm{mg} / 200 \mathrm{gBW}$ (P3; P4; and P5). The neem leaf ethanolic extract was administered every day in the afternoon. High-fat ration in the form of a mixture of commercial feed and used cooking oil was given every day in the morning, while duck egg yolk was given every two day in the morning. The treatment was given orally for 44 days. The rats were weighed every week, while the food consumption was measured every day.

\section{Analyzing and determining the blood glucose levels of serum}

Blood glucose levels of serum were analyzed by colorimetric enzymatic method using Roche Diagnostics Cobas C reagents kits. Blood serum glucose level was determined using Roche / Hitachi cobas c systems automatically.

\section{Data analysis}

Homogeneous and normally distributed data of blood-glucose levels body weight, and feed consumption were analyzed statistically using ANOVA followed by the Duncan's test with a significance level of 5\% using SPSS 16.0 software.

\begin{abstract}
Research ethics
All experimental protocols used in this study have been approved by the Ethical Committee for Experimental Animal Use of Faculty of Medicine, Diponegoro University (No. 101/EC/H/FKUNDIP/X/2020)
\end{abstract}

\section{RESULTS AND DISCUSSION}

The results of the average analysis of blood glucose, body weight and feed consumption of white rats given high fat ration after administered with neem leaf ethanolic extract are presented on (Table $3)$.

Table 3. The mean of blood glucose levels, body weight, and feed consumption of white rats

\begin{tabular}{cccc}
\hline \multirow{2}{*}{ Treatment } & \multicolumn{3}{c}{ Variable } \\
\cline { 2 - 4 } & The mean blood glucose levels $(\mathrm{mg} / \mathrm{dl}) \pm$ & $\begin{array}{c}\text { The mean } \\
\text { body weight }(\mathrm{g}) \pm \text { SD }\end{array}$ & $\begin{array}{c}\text { The mean } \\
\text { feed consumption }(\mathrm{g}) \pm \mathrm{SD}\end{array}$ \\
\hline P0 & SD & $245^{\mathrm{a}} \pm 19.15$ & $14.8^{\mathrm{a}} \pm 1.8$ \\
P1 & $107.77^{\mathrm{b}} \pm 1.87$ & $267.5^{\mathrm{a}} \pm 15$ & $16.6^{\mathrm{a}} \pm 1.1$ \\
P2 & $125.12^{\mathrm{a}} \pm 2.73$ & $222.5^{\mathrm{a}} \pm 45$ & $14.1^{\mathrm{a}} \pm 1.3$ \\
P3 & $106.32^{\mathrm{bc}} \pm 1.42$ & $220^{\mathrm{a}} \pm 18.26$ & $13.9^{\mathrm{a}} \pm 1.8$ \\
P4 & $105.70^{\mathrm{bc}} \pm 0.95$ & $247.50^{\mathrm{a}} \pm 9.57$ & $15.2^{\mathrm{a}} \pm 1.5$ \\
P5 & $105.02^{\mathrm{cd}} \pm 1.25$ & $235^{\mathrm{a}} \pm 43.59$ & $13.8^{\mathrm{a}} \pm 1.3$
\end{tabular}

Note: Numbers with different superscripts for the same column show a significant difference between treatments at the 5\% significance level $(\mathrm{P}<0.05)$. The control group ( $\mathrm{P} 0)$; given high fat rations + duck egg yolk $2.5 \mathrm{ml} / 200 \mathrm{gBW}$ ( $\mathrm{P} 1$ ); given high fat rations $+8 \mathrm{mg} / 200 \mathrm{gBW}$ simvastatin (P2); and $\mathrm{P} 1+$ the dose of neem leaf ethanolic extract of 75 ; 100 ; and 125 $\mathrm{mg} / 200 \mathrm{gBW}$ (P3; P4; and P5).

Blood sugar is sugar that is distributed in the blood from dietary carbohydrates or from glycogen stores in the liver and muscles, absorption sugar from the intestine and the breakdown of glycogen into a source of blood sugar. The results of this study indicated an increase in blood glucose levels after the oral administration of high fat ration with a high enough fat content $(12.07 \% \mathrm{WB})$ and chlolesterol $(0.74 \mathrm{mg} / \mathrm{g})$ compared to a commercial ration with $4.70 \% \mathrm{WB}$ fat and $0.48 \mathrm{mg} / \mathrm{g}$ cholesterol content (Table 1 and 2). An increase in blood sugar after giving high-fat ration is an indication of type 2 diabetes. The results of previous research by Isdadiyanto et al. (2020) stated that giving high-fat rations causes hyperlipidemia.

Based on the Table 3, the research data showed an increase of blood glucose levels at P1 (positive control group). It shows that high-fat rations can increase blood glucose levels. The results of the analysis with the Duncan's test showed that the blood glucose levels at the end of treatment are as follows: $\mathrm{P} 0$ were significantly different from P1, P4 and P5; 
P1 was significantly different from P0, P2, P3, P4 and P5; P2 was significantly different from $\mathrm{P} 1$ and P5; P3 was significantly different from P1 and P5; P4 was significantly different from $\mathrm{P} 0$ and $\mathrm{P} 1$ : P5 is significantly different from P0, P1, P2, P3. This showed that the neem leaf ethanolic extract at doses of 75,100 and $125 \mathrm{mg} / 200 \mathrm{gBW}$ had a significant effect on the levels of blood glucose of white rats given by high fat rations. This was likewise the results of research by Ningrum et al. (2020) stated that the neem at doses of 75,100 , and $125 \mathrm{mg} / \mathrm{gBW}$ could not increase the diameter and area of Langerhans of white rats fed high-fat diets. In addition, there were no significant changes in the pancreatic histopathology of white rats fed high-fat feed and exposure to neem (Azadirachta indica A. Juss) at various doses $(75,100$, and $125 \mathrm{mg} / 200 \mathrm{gBW}$. The dose is still classified as safe for consumption and can be tolerated by the body of white rats and the antioxidant content of neem leaf ethanol extract is able to improve the structure of the cells of the islets of langerhans from damage.

The reduction in blood glucose levels is presumed to be influenced by the content of 6 compounds in neem leaf ethanolic extract, especially quercetin-3-OL-rhamnoside, kaempferol-3-O-B-D-glucoside, quercetin-3-O-Routoside, kaempferol-3-O-Routoside, myricetin-3-0-Routoside,

quercetin-3-O-B-Dglucoside which can be an agent in decreasing blood glucose levels in test animal. Flavonoids, especially quercetin, can act as activators of the phosphoinositide 3-kinase (PI3K) pathway. Based on the statement of Russo et al. (2019), quercetin which is included in the flavonoid class is known to increase insulin sensitivity by restoring the bond between the insulin receptor (IR) and the insulin receptor substrate (IRS1). The bond between IR and IRS1 causes the PI3K pathway to become active so that it causes the translocation of GLUT 4 to return to normal and makes glucose in the blood stable.

Flavonoid compounds are good reducing compounds, they are able to capture free radicals namely Reactive Oxygen Species (ROS) or Reactive Nitrogen Species (RNS) through electron transfer and inhibition of peroxidation reactions. Flavonoids are known to act directly on pancreatic beta cells, by triggering the activation of the cAMP signal cascade in strengthening glucose-sensitive insulin secretion (Tandi et al. 2016 ${ }^{\mathrm{a}}$ ). Alkaloids play a role in lowering blood glucose by reducing glucose absorption in the intestine, intensifying glucose transport in blood, energizing glycogen synthesis and prohibits glucose synthesis by prohibiting the enzyme glucose 6phosphatase, fructose 1,6-bisphosphatase, and glucose oxidation by way of glucose 6 - phosphate dehydrogenase is enhanced (Tandi et al. $2016^{\mathrm{b}}$ ).
Phenols are antioxidants that reduce oxidative stress by avoiding the chain transformation reaction of superoxide to hydrogen superoxide by giving hydrogen atoms from the aromatic hydroxyl $(-\mathrm{OH})$ groups to attach to free radicals and secrete them from the body by way of the excretion system (Tandi et al., 2017). Flavonoid antioxidants are able to prevent superoxide from turning into hydrogen superoxide. This can cause the production of ROS to decrease, so that the occurrence of oxidative stress will be inhibited and inflammation and the release of proinflammatory cytokines TNF- $\alpha$ does not occur (Choy et al., 2019).

Giving high-fat ration to mice can affect the expression of pancreatic $\beta$ cell genes which can cause abnormality and programmed cell death of pancreatic $\beta$ cells (Dusaulcy et al., 2019).. This matter is in accordance with the research of Sartika et al. (2016) that there was a change in the number of normal $\beta$ cells to be reduced in the pancreas of Wistar rats given trans-fatty acids. This is supported by the opinion that trans-fat is believed to be a source of oxidative stress is a condition in which there is an excess of ROS which are free radicals because of instability the betwen producing rate and the ROS disposal rate due to excess ROS production (Martin et al., 2007 \& McMichael, 2007). Oxidative stress is highly correlated with various metabolic diseases and inflammatory conditions (Noeman et al., 2011) such as acute (Andican et al., 2005) and chronic pancreatitis. Oxidative stress is thought to have an impact on the damage to acinar cells, thereby triggering autodigestion of the pancreas (Verlaan et al., 2006) which leads to degeneration and necrosis of pancreatic $\beta$ cells (Tjahjono et al., 2013).

In this study showed that there was a change in the body weight of experimental animals from before and after treatment. Difference on body weight was due to the amount of at least intake rations from each treatment group. However, the ANOVA test results indicated no significant difference $(\mathrm{P}>0.05)$ as presented in Table 3, even though the highest increase in body weight was showed by P1. It can be assumed that enhancement of the body weight that occurred in this group was not significant or not affected by the neem leaf ethanolic extract given. Generally, people with diabetes or hyperglycemia experience a decrease in body weight, this can be caused by impaired transportation of glucose into cells. This is associated with impaired translocation of GLUT 4 to skeletal muscles which results in a lack of glucose intake in the muscles. According to Russo et al. (2019), disruption of GLUT 4 and the PI3K pathway causes a decrease in glucose levels in cells and an increase in the blood glucose levels. An increase in body weight occurred in the P1 group 
because the results of feed consumption were stored in the form of muscle and fat in adipose cells. According to the statement by Hill et al. (2012), excess glucose in the body will be converted into glycogen which can cause mass gain in muscle and fat tissue.

The results of the ANOVA of feed consumption of test rats indicated no significant difference $(\mathrm{P}>$ 0.05 ) as presented in Table 3 even though there was an increase in feed consumption of rats in P1. It can be assumed that enhancement of the feed consumption that occurred in this group was not significant or not affected by the neem leaf ethanolic extract given. Ozougwu et al. (2013), stated that diabetics have high blood glucose levels in the blood because glucose cannot enter the cells. This causes stimulation to the brain to send hunger signals continuously. Therefore, feed consumption increase or often referred to as polyphagia. According to Ahima and Antwi (2008), high glucose level will stimulate the center of satiety found in the ventromedial nucleus in the hypothalamus and on the other hand, low glucose level stimulated neurons in the hungry center (feeding center) contained on the lateral nucleus in the hypothalamus. Stimulation of this feeding center results in increased hunger. Satiety center affects the emergence of a feeling of fullness after eating. This feeling of fullness is due an increase in blood glucose levels after we eat causes increased glucose passing through satiety center and activate it. High and low levels blood glucose which affects the activity of satiety center or feeding center, is called glucostatic theory. In this study, it was not proven that there was an increase in feed consumption in hyperlipidemic rats.

Administration of high-fat rations in the long term will have an impact on the incubation of the islets of Langerhans by free fatty acids which affect insulin secretion (Collins et al., 2010) which correlates with an increase in the number of fat in islets of Langerhans (Hoppa et al., 2009) and exocrine of pancreas around it (Pinnick et al., 2008). Based on this study, high-fat rations statistically proven to lower blood glucose levels.

Neem leaf is a medicinal plant, there needs to be a deeper study so that its utilization is more optimal. In the future, it is necessary to conduct a research to determine the levels of each phytochemical in neem leaves in order to obtain compounds that play an active role as antidiabetics. In study, the neem leaf ethanolic extract has been confirmed to lower blood glucose levels. Thus, this study informs about the potential sources of local medicinal plants, namely neem leaves for the treatment of diabetes mellitus.

\section{CONCLUSION}

The outcome of this study indicated that giving the neem leaf ethanolic extract could reduce blood glucose levels. It is concluded that the neem leaf ethanolic extract could potentially be used as an alternative to cure diabetes mellitus.

\section{ACKNOWLEDGEMENTS}

This research was funded by PNBP in 2019 of the Faculty of Science and Mathematics, Diponegoro University, Semarang Indonesia.

\section{REFERENCES}

Ahima, R. S.M.D. \& Antwi, D. A. (2008). Brain regulation of appetite and satiety. Endocrinol Metab. Clin. North Am., 37(4), 811- 823.

Alzohairy, M. A. (2016). Therapeutics role of Azadirachta indica (Neem) and their active constituents in diseases prevention and treatment. Evidence-Based Complementary and Alternative Medicine, 2016.

Andican, G., Gelisgen, R., Unal, E., Tortum, O. B., Dervisoglu, S., Karahasanoglu, T., \& Burçak, G. (2005). Oxidative stress and nitric oxide in rats with alcohol-induced acute pancreatitis. World Journal of Gastroenterology: WJG, 11(15), 2340.

Chattopadhyay, R. R. (1999). Possible mechanism of antihyperglycemic effect of Azadirachta indica leaf extract: part V.Journal of Ethnopharmacology, 67(3), 373-376.

Chattopadhyay, R.R. \& Bandyopadhyay, M. (2005). Effect of azadiractha indica leaf extract on serum lipid profil changes in normal and streptozotocin induced diuretic rats.African $J$. of Biomedical Research, 8, 101-104.

Collins, S. C., Hoppa, M. B. Walker, J. N. Amisten, S. Abdulkhader, F. \& Bengtsson, M. (2010). Progression of diet-induced diabetes in C57B16J mice involves functional dissociation of $\mathrm{Ca} 2+$ channels from secretory vesicles. J. Diabetes, 1(59), 1192-1201.

Choy, K. W. Murugan, D., Leong, X. Abas, R. Alias, A. \& Mustafa, M. R. (2019). Flavonoids as Natural Anti- Inflammatory Agents Targeting Nuclear Factor-Kappa B (NFkB) Signaling in Cardiovascular Diseases: A Mini Review. Fronti Pharmacol, 10, 1295.

Debashri, M. \& Mondal, T. (2012). A Review on efficacy of Azadirachta indica A. Juss based biopesticides: An Indian perspective. Research Journal of Recent Sciences, 1(3), 94-99.

Dusaulcy, R. Handgraaf, S. Visentin, F. Howald, C. Dermitzakis, E. T. Philippe, J. \& Gosmain, Y. 
(2019). High-fat diet impacts more changes in beta-cell compared to alpha-cell transcriptome. PLOS ONE, 14(3), 1-16.

Foley, E. Akhavan, N. George, K. Siebert, S. \& Munoz, J. (2019). Body Composition in Subjects with Prediabetes and Type 2 Diabetes. Current Developments in Nutrition, 3(1), 8-29.

Hanung, A. Fanti S. \& Ainun, R. (2019). Pengaruh Frekuensi Penggorengan Minyak Jelantah Terhadap Diameter dan Gambaran Histopatologi Lumen Aorta Tikus Wistar (Rattus novergicus). Jurnal Kedokteran Diponegoro, 8(1), 26-37.

Hasana, A. Sitasiwi, A. \& Isdadiyanto, S. (2019). Hepatosomatik Indeks dan Diameter Hepatosit Mencit (Mus musculus L.) Betina Setelah Paparan Ekstrak Etanol Daun Mimba (Azadirachta indica Juss.). Jurnal Pro-Life, 6(1), 1-12.

Hao, M. Head, W. S. Gunawardana, S. C. Hasty, A. H. \& Pitson, D. W. (2007). Direct Effect of Cholesterol on Insulin Secretion. Diabetes, 56(9), 2328-2338.

Hill, R. W. Wyse, G. A. \& Anderson, M. (2012). Animal Physiology Third Edition. Sinauer Associates Inc: Massachusetts.

Hoppa, M. B. Collins, S. Ramracheya, R. Hodson, L. Amisten, S. \& Zhang, Q. (2009). Chronic palmitate exposure inhibits insulin secretion by dissociation of $\mathrm{Ca}(2+)$ channels from secretory granules. Cell Metab, 1(10), 455-465.

Isdadiyanto, S. Sitasiwi, A.J. \& Mardiati, S.M. (2020). The Lipid Profile of Rats (Rattus norvegicus L.) Induced by High Fat Ration after Exposed to Ethanolic Neem (Azadirachta indica) Leaf Extract. J. Phys: Conf. Ser., 1524, 012126.

Jannah, B. M. Isdadiyanto, S. \& Sitasiwi, A. J. (2020). Histopathological of White Rats Aorta Induced by High-Fat Feed After Administered by Neem Leaf Ethanolic Extract. Biosaintifika: Journal of Biology \& Biology Education, 12(3), 370-378.

Kahn, S. E., Hull, R. L. \& Utzschneider, K. M. (2006). Mechanisms Linking Obesity to Insulin Resistance and Type 2 Diabetes. Nature, 444(7121), 840-846.

Martin, C. A. Milinsk, M. C. Visentainer, J. V. Matsushita, M. \& De-Souza, N. D. (2007). Trans fatty acidforming processes in foods: a review. $A n$ Acad Bras Cienc, 1(79), 343-350.

McCance, K. L. \& Huether, S. E. (2014). Pathophysiology: The Biologic Basis for Disease in Adults and Children. Edisi ke-7. St. Louis, Mosby.

McMichael, M. A. (2007). Oxidative stress, antioxidants, and assessment of oxidative stress in dogs and cats. J. Am Vet Med Assoc, 231(5), 71420.
Muhartono, M., Putri, N. T., Sari, T. N., \& Oktafany, O. (2018). Minyak Jelantah Menyebabkan Kerusakan pada Arteri Koronaria, Miokardium, dan Hepar Tikus Putih (Rattus norvegicus) Jantan Galur Sprague dawley. Jurnal Kedokteran Universitas Lampung, 2(2), 129-135.

Munshi, R. P. Joshi, S. G. \& Rane, B. N. (2014). Development of an experimental diet model in rats to study hyperlipidemia and insulin resistance and markers for coronary heart disease. Indian Journal of Pharmacology, 46(3), 271-276.

Ningrum, E.W.C. Isdadiyanto, S. \& Mardiati, S. M. (2020). Histopathology of Pancreas in

White Rats (Rattus norvegicus L.) that Given with High-Fat Diet and Neem Leaf Ethanol

Extract (Azadirachta indica A. Juss). Buletin Anatomi dan Fisiologi, 5(2), 23-28

Noeman, S. A. Hamooda, H. E. \& Baalash, A. A. (2011). Biochemical study of oxidative stress markers in the liver, kidney and heart of high fat diet induced obesity in rats. Diabetol Metabol Synd., 3(17), 1-8.

Ozougwu, J.C. Obimba, K.C. Belonwu, C.D. \& Unakalamba, C.B. (2013). The Pathogenesis and Pathophysiology of Type 1 and Type 2 Diabetes Mellitus. Academic journal:Journal of Physiology and Pathophysiology, 4(4), 46-57.

Pinnick, K. E. Collins, S. C. Londos, C. Gauguier, D. Clark, A. \& Fielding, B. A. (2008). Pancreatic ectopic fat is characterized by adipocyte infiltration and altered lipid composition. Obesity (Silver Spring), 1(6), 522-530.

Russo, B. Picconi, F. Malandrucco, I. \& Frontoni, S. (2019). Flavonoids and Insulin-Resistance: From Molecular Evidences to Clinical Trials. International Journal of Molecular Sciences, 2061

Sartika, R. T. A. D. Achmad, K. Triyanti, \& Rustika. (2016). Effect of Trans Fatty Acid on Glucose Level and Pancreatic $\beta$ Cell in Rats. Pakistan Journal of Nutrition, 15(8), 760-762.

Satyanarayana, K. Sravanthi, K. Shaker, I. A. \& Ponnulakshmi, R. (2015). Molecular Approach to Identify Antidiabetic Potential of Azadirachta indica. J. Ayurveda Integrative Med, 6(3), 165174.

Supriyanto, Simon, B. Rifa'i, M. \& Yunianta. (2017). Uji Fitokimia dan Aktivitas Antioksidan Ekstrak Daun Mimba (Azaradiracta indica Juss). Prosiding SNATIF ke-4. Fakultas Teknik, Universitas Muria Kudus.

Tandi, J. Muthi'ah H Z. \& Yuliet. Y. $\left(2016^{\mathrm{a}}\right)$. Efektivitas Ekstrak Daun Gedi Merah Terhadap Glukosa Darah, Malondialdehid, 8-HdroksiDeoksiguanosin, Insulin Tikus Diabetes," Trop. Pharm. Chem, 3(4), 264-276. 
Tandi, J. As'ad, S. Natzir, R. \& Bukhari, A. (2016 $)$. Test Of Ethanolextract Red Gedi Leaves (Albelmoschus Manihot. (L.) Medik) In White Rat (Rattus Norvegicus) Type 2 Diabetes Mellitus. International Journal Of Sciences, 30(4), 84-94.

Tandi, J. Rakanita, Y. Hastuti \& Mulyani, S. (2017). Efektivitas Anthihiperurisemia Ekstrak Etanol Daun Seledri (EEDS) Pada Tikus Induksi Oksalat. Journal Of Tropical Pharmacy And Chemistry, 4(1), 1-6.

Tembe-Fokunang, E. A. Charles, F. Kaba, N. Donatien, G. Michael, A. \& Bonaventure, N. (2019). The Potential Pharmacological and Medicinal Properties of Neem (Azadirachta indica A. Juss) in the Drug Development of
Phytomedicine. Journal of Complementary and Alternative Medical Research, 7(1), 1-18.

Tjahjono, K., Santoso, \& Ngestiningsih, D. (2013). Trans fatty acids increase nitric oxide levels and pancreatic beta-cell necrosis in rats. Univ Med., 32(1), 51-59.

Tuminah, S. (2009). Efek Asam Lemak Jenuh dan Asam Lemak Tak Jenuh "Trans" terhadap Kesehatan. Media Peneliti dan Pengembang Kesehatan, 1(19), 13-20.

Verlaan, M. Roelofs, H. M. J. Van Schaik, A. Wanten, G. J. A. Jansen, J. B. M. J. Peters, W. H. M. \& Drenth, J. P. H. (2006). Assessment of oxidative stress in chronic pancreatitis patients. World J. Gastroenterol, 12(35), 5705-5710. 